\title{
Imigran Cina: Peranannya Dalam Sejarah Perdagangan Di Indonesia
}

\section{Andi Nuralang}

Keywords: trading, archaeology of economy, settlement, chinese, ethnic, history

\section{How to Cite:}

Nuralang, A. (2002). Imigran Cina: Peranannya Dalam Sejarah Perdagangan Di Indonesia. Berkala Arkeologi, 22(1), 58-65. https:// doi.org/10.30883/jba.v22i1.850

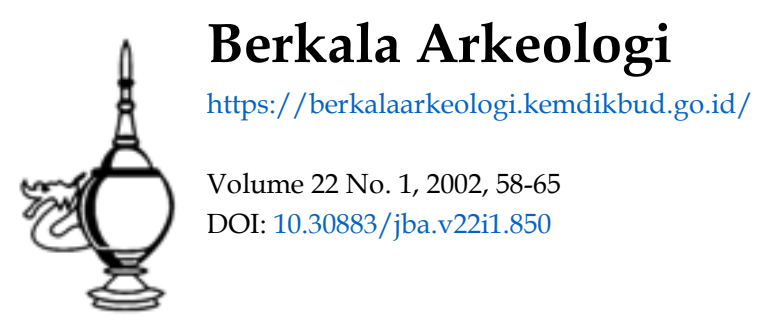

\section{(c) (1) (2)(2)}

This work is licensed under a Creative Commons Attribution-NonCommercial-ShareAlike 4.0 International License. 


\title{
IMIGRAN CINA : PERANANNYA DALAM SEJARAH PERDAGANGAN DI INDONESIA
}

\author{
Andi Nuralang \\ (Balai Arkeologi Banjarmasin)
}

\section{Latar Belakang}

Migrasi etnis Cina terjadi secara besar-besaran setelah terjadinya perang Candu (1839 - 1842) yang mengakibatkan terbukanya Negara Cina oleh Inggeris dan terjadinya pemberontakan Tai Ping (1851 - 1865) yang mengakibatkan hancurnya perekonomian di Cina Selatan. Dengan hancurnya perekonomian mereka, maka banyak orang Cina meninggalkan kampung halamannya untuk memperoleh atau mendapatkan kehidupan yang lebih baik.

Para imigran Cina yang tersebar di Indonesia mulai abad ke-16 dan pertengahan abad ke-19 asal dari suku bangsa Hokkien dari Propinsi Fukien bagian selatan dan Imigran Cina lainnya adalah orang Teo -Chiu yang berasal dari pantai selatan negeri Cina di daerah pedalaman Swatow di bagian timur propinsi Kwantung. Sejak akhir abad ke18 orang Hakka mulai berimigrasi ke Jawa Barat karena tertarik oleh perkembangan kota Jakarta dan karena dibukanya daerah Priangan bagi pedagang Cina. Kini banyak orang Hakka menetap di Jakarta dan di daerah Jawa Barat. Di sebelah Barat dan Selatan daerah asal orang Hakka di Propinsi Kwantung, tinggallah orang Kanton atau juga dikenal sebagai orang Kwong-Fu. Imigran Cina lainnya tinggal di Kalimantan Selatan terkonsentrasi di Kelurahan Cempaka dan Kelurahan Veteran Banjarmasin Kalimantan Selatan, bahkan meliputi seluruh pulau Kalimantan.

Dominasi perekonomian di Asia Tenggara oleh golongan Cina menimbulkan banyak gejolak seperti dipaparkan oleh Lie Tek Tjeng, seorang ahli peneliti utama di PPW LIPI, bahwa Asia Tenggara merupakan suatu masyarakat heterogen. Dan, pemerintahpemerintah kolonial yang berkuasa di zaman modern sampai perang dunia II tidak berusaha menyatukan golongan etnik yang berbeda-beda menjadi satu bangsa. Lagi pula, pemerintah kolonial Barat menjalankan politik devide et impera, khususnya terhadap golongan Cina. Hal ini terjadi karena kombinasi ketekunan golongan etnik Cina dan politik kolonial yang mendorong dan meneloransi mereka di bidang perdagangan dan ekonomi berakibat terbentuknya golongan menengah yang didominasi golongan Cina dan menguasai Asia Tenggara (Tjeng 1998).

Berdasarkan hal tersebut di atas, penulis akan memaparkan secara sederhana bagaimana imigran Cina dapat berhasil di tanah rantau seperti Indonesia pada umumnya ? Berdasarkan bukti-bukti arkeologis dan historis yang ditemukan selama 
beberapa dasawarsa penelitian arkeologi dan penelitian ilmu-ilmu lainnya di Indonesia. Permasalahan seputar kedatangan imigran Cina di Indonesia berdasarkan bukti arkeologis dan historis, peranannya dalam dunia perdagangan sehingga dapat meningkatkan taraf perekonomian mereka dan Indonesia sendiri.

\section{Bukti Arkeologis dan Historis Tentang Kedatangan Imigran Cina}

Berdasarkan penelitian Balai Arkeologi Banjarmasin, pada Pesisir Tenggara Kalimantan Selatan ditemukan bukti arkeologis berupa kuil Buddhis yaitu Kelenteng An Hwa Tian. Hal ini menunjukkan bahwa orang Cina pernah eksis di Kalimantan Selatan. Profesi orang Cina tersebut bukan hanya berdagang melainkan juga sebagai pekerja tambang batubara di Semblimbingan (Lindblad 1988; Kusmartono dan Nuralang 2000). Pagoda dalam variasi arsitektur dan dimensinya serta penggambaran bentuk lahan purba juga dapat ditemukan pada kelenteng-kelenteng yang terdapat di Kelurahan Cempaka dan Kelurahan Veteran di Banjarmasin Kalimantan Selatan. Temuan arkeologis lainnya di situs tersebut di atas, selain Kelenteng yaitu ditemukannya keramik-keramik Cina yang secara kronologi keramik tertua berasal dari Cina abad ke-14 Masehi berupa piring seladon utuh (warisan) berhiasan motif lundang-lundang, yaitu Longguan ware. Kronologi keramik lainnya berasal dari abad ke-16 sampai dengan ke-17 hingga 19 akhir 20 Masehi (Kusmartono dan Nuralang
2000 ).

Bila kita telusuri sejarah perkembangan mereka dalam bidang perekonomian, maka kita harus melihat kenyataan, bahwa bangsa Cina telah mengadakan hubungan dengan bangsa-bangsa di Asia Tenggara, termasuk Indonesia sejak jaman Dinasti Han berkuasa di negeri Cina (206 SM - $221 \mathrm{M}$ ). Yang pertama-tama mengadakan hubungan dengan bangsa Indonesia diduga adalah rombongan pedagang. Beberapa bukti arkeologis menunjukkan antara lain adanya patung-patung batu yang diketemukan di Pasemah, Sumatera Selatan yang mirip dengan patung-patung batu yang terdapat pada kuburan Jenderal Huo K'iu-ping di Propinsi Shenshi yang bertandakan tahun $117 \mathrm{SM}$. Di samping itu pula banyak diketemukan barang-barang keramik di Sumatera, Jawa dan Kalimantan yang bertandakan tahun 45 SM. Menurut para ahli di duga masa tersebut merupakan masa awal hubungan Cina Indonesia.

Hubungan berikutnya adalah datangnya para musafir Cina yang beragama Budha ke Indonesia. Fa Hien datang ke Jawa pada tahun $413 \mathrm{M}$. Dari catatan sejarah Dinasti Sung (420-479) dan Dinasti Liang (502-527) dapat diketahui bahwa ada utusan dari negara-negara di Asia Tenggara yang datang ke Cina. Selain utusan yang datang ke Cina, Cina sendiri pada jaman Dinasti T'ang $(618-907)$ pernah mengirim utusan ke Selatan untuk membuka hubungan dagang. Pada tahun 756-779 pernah datang tiga utusan dari Jawa ke Cina. Dengan adanya pengiriman utusan baik dari Jawa ke Cina 
atau sebaliknya, maka hubungan dagang utara selatan menjadi semakin lancar. Pada jaman pemerintahan Dinasti Yuan (1280-1368) Kubilai Khan pernah mengirimkan expedisi militernya ke Singapura pada tahun 1292, tetapi expedisi ini mengalami kegagalan.

Pada masa pemerintahan Dinasti Ming (1368-1644) salah seorang Kaisar Ming pernah mengirim expedisi militer dibawah pimpinan Cheng Ho ke daerah-daerah di Selatan Cina antara tahun 1405-1431. Selain mengunjungi daerah-daerah Asia Tenggara, expedisi ini juga sampai ke Ceylon dan Calicut. Peninggalan dari expedisi ini di Indonesia adalah kota Semarang, yang menurut sejarahnya kota Semarang didirikan oleh salah seorang jurumudi Cheng Ho. Dari catatan expedisi ini juga disebutkan bahwa Tuban dan Surabaya adalah merupakan kota yang banyak penduduk etnis cinanya.

Mengkaji tentang hubungan Asia Timur pada zaman kuna sudah terjadi terutama dengan Cina dalam bentuk hubungan perdagangan. Dalam hubungan dagang ini Indonesia berperan aktif. Kapal-kapal Indonesia melayani jalur-jalur pelayaran dan perdagangan dari India sampai ke Cina pada awal abad ke-7. It Sing seorang pendatang Budha Cina telah bertolak ke Indonesia menumpang kapal Sriwijaya tetapi pengaruh Cina terhadap Indonesia sebagai akibat perdagangan ini jauh lebih kecil dibandingkan dengan pengaruh India. Bila disesuaikan dengan teori perubahan sosial historis dengan pola perubahan sosial dari Pitirin A Sorokin, maka perubahan sosial yang ditimbulkan ataupun pengaruh Cina itu antara lain dalam bentuk :

a) Tersebarnya barang persolen di seluruh kepulauan Indonesia. Barang-barang ini di banyak tempat mempunyai nilai yang tinggi lebih dari sekedar nilai ekonomis.

b) Migrasi penduduk Cina ke Indonesia memberi warna tersendiri terhadap komposisi penduduk.

c) Resep-resep masakan Cina berpengaruh pada resep-resep makanan Indonesia.

d) Pengobatan tradisional Cina dan ramuan obat tradisionalnya banyak mempengaruhi Indonesia.

e) Dalam bidang arsitektur pengaruh Cina terutama terdapat di daerah perkampungan Cina, daerah pertokoan, kelontong dan sebagainya.

f) Seni bela diri kungfu Cina banyak berpengaruh pada seni bela diri pencak silat Indonesia.

g) Ragam hias dan batik Indonesia banyak diperkaya dengan motif-motif dari Cina, seperti motif gunung batu, motif burung phoenix, awan, motif naga dan seterusnya.

h) Banyak musafir Cina yang datang ke Indonesia dan menuliskan kesan-kesannya telah melahirkan sumber sejarah yang disebut berita Cina. 


\section{Peranan Imigran Cina Dalam Dunia Perdagangan di Indonesia}

Golongan etnis Cina di Indonesia seringkali diidentifikasikan sebagai golongan yang mempunyai peranan penting dalam dunia perekonomian di Indonesia. Walaupun sebetulnya tidak semua orang Cina mempunyai bakat dalam dunia bisnis. Karena hanya Hokkienlah yang lebih mendominasi mempunyai jiwa dalam dunia perdagangan. Orang Hakka dan Te-Chiu umpamanya lebih dikenal sebagai buruh dan pekerja kasar. Tetapi karena pengaruh peranan Cina dalam dunia perdagangan inilah yang menyebabkan timbul anggapan bahwa semua orang Cina yang ada di Indonesia adalah pedagang.

Peranan orang Cina dalam dunia perdagangan ini tidak dapat dipisahkan dari adanya kenyataan, bahwa mereka telah mulai merintis usaha-usaha di bidang perekonomian sejak lama dan keberhasilan mereka ditunjang oleh banyak faktor. Faktor-faktor tersebut berasal dari berbagai pihak, baik pihak mereka sendiri terkenal ulet, tahan uji dan rajin, baik pihak pemerintah Hindia Belanda yang memberi peluang kepada mereka dan bangsa kita sendiri.

Para imigran Cina yang tersebar ke Indonesia mulai abad ke-16 dan pertengahan abad ke-19 asal dari suku bangsa Hokkien. Mereka berasal dari propinsi Fukien bagian selatan. Daerah ini merupakan daerah sangat penting dalam pertumbuhan perdagangan Orang Cina ke seberang lautan. Kepandaian berdagang ini yang dimiliki suku bangsa Fukien telah ada sejak berabad-abad lamanya dan masih tampak jelas pada orang Cina di Indonesia. Diantara pedagang-pedagang Cina di Indonesia bangsa Fukienlah yang paling berhasil. Hal itu disebabkan suku Fukien ini mempunyai mentalitas tersendiri yang sangat cocok sebagai pedagang yaitu bahwa mereka ini sangat ulet, tahan uji dan rajin. Orang Hokkien dan keturunannya yang telah berasimilasi sebagai keseluruhan paling banyak terdapat di Indonesia bagian Timur, Jawa Tengah, Jawa Timur dan pantai Barat Sumatera.

Orang Teo-Chiu dan Hakka atau Khek sangat disukai sebagai kuli perkebunan dan pertambangan di Sumatera Timur, Bangka dan Biliton. Walaupun orang Hakka suku bangsa Cina yang paling banyak merantau ke seberang lautan, mereka bukan suku bangsa maritim. Pusat daerah mereka adalah di pedalaman Propinsi Kwantung yang terutama terdiri daerah pegunungan kapur yang tandus. Orang Hakka merantau karena terpaksa atas kebutuhan untuk mencari mata pencaharian untuk hidup.

Selama berlangsungnya gelombang-gelombang imigrasi dari tahun 1850 sampai 1930 orang Hakka adalah yang paling miskin diantara para perantau Cina. Mereka bersamasama orang Teo-Chiu diperkerjakan di Indonesia untuk mengeksploitasi sumbersumber mineral yaitu di daerah pertambangan, sehingga sampai sekarang orang Hakka mendominasi masyarakat Cina di distrik-distrik tambang mas lama di Kalimantan 
Barat, didaerah bekas tambang mas Kerajaan Banjar di daerah Pleihari Kalimantan Selatan yang dikenal dengan sebutan Cia Parit Sumatera, Bangka dan Biliton. Kemungkinan besar orang Cina yang bekerja ditambang batubara pantai Timur Kalimantan Selatan seperti yang dipaparkan oleh Lindblad juga berasal dari daerah yang sama.

Sebagaimana orang Hakka, orang Kanton terkenal di Asia Tenggara sebagai kuli pertambangan. Mereka berimigrasi dalam abad ke-19 ke Indonesia, sebagian besar karena tertarik oleh tambang-tambang timah di pulau Bangka. Walaupun mereka mulai merantau ke Indonesia dalam kelompok-kelompok pada waktu yang sama dengan orang Hakka namun keadaan mereka berlainan. Umumnya mereka datang dengan modal uang yang lebih besar dan mereka datang dengan keterampilan teknis dan pertukangan yang tinggi. Di Indonesia mereka terkenal sebagai ahli pertukangan, pemilik toko-toko besi dan industri kecil. Orang Kanton jauh lebih tersebar merata di seluruh kepulauan Indonesia, kalau dibandingkan dengan orang Hokkian, Teo-Chiu atau Hakka. Walaupun demikian tidak banyak dari mereka tersebar di Jawa Tengah dan Timur, Kalimantan Selatan dan Timur, Bangka dan sumatera tengah (Usman, 1996).

Orang Cina yang ada di Indonesia sebenarnya bukan merupakan satu kelompok dan juga tidak berasal dari satu daerah di negeri Cina, tetapi berasal dari beberapa suku bangsa dari dua propinsi, yaitu Fukien dan Kwantung dan daerahnya terpencarpencar. Setiap orang Cina yang berimigrasi ke Indonesia mereka membawa kebudayaannya sendiri, termasuk juga perbedaan bahasa yang mereka pergunakan. Orang Cina yang ada di Indonesia terdiri dari empat jenis bahasa, yang satu dengan lain sangat besar perbedaannya sehingga mereka antar suku bangsa tersebut tidak dapat berkomunikasi satu dengan lainnya. Keempat bahasa itu adalah bahasa Hokkien, Hakka, Teo-Chiu dan bahasa Kanton.

Di sebelah barat dan selatan daerah asal orang Hakka di propinsi Kwantung, tinggallah orang Kanton atau juga dikenal sebagai orang Kwong-Fu. Sebagaimana orang Hakka, orang Kanton terkenal di Asia Tenggara sebagai kuli pertambangan. Mereka berimigrasi dalam abad ke-19 ke Indonesia, sebagian besar karena tertarik oleh tambang-tambang timah di Pulau Bangka. Walaupun mereka mulai merantau ke Indonesia dalam kelompok-kelompok pada waktu yang sama dengan orang Hakka namun keadaan mereka berlainan. Umumnya mereka datang dengan keterampilan teknis dan pertukangan yang tinggi. Di Indonesia mereka terkenal sebagai ahli pertukangan, pemilik toko-toko besi dan industri kecil. Orang Kanton jauh lebih tersebar merata di seluruh kepulauan Indonesia, kalau dibandingkan dengan orang Hokkien, Teo-Chiu atau Hakka. Walaupun demikian tidak banyak dari mereka tersebar di Jawa Tengah dan Timur, Kalimantan Selatan dan Timur, Bangka dan Sumatera Tengah. Ketika Sriwijaya runtuh, kota Palembang jatuh ketangan etnis Cina 
dan merupakan tempat pemukiman etnis Cina pertama di Asia Tenggara. Mereka mempunyai pemerintahan sendiri dan pernah mengirim utusan ke Kwantung-Cina Selatan pada tahun 1377.

Setelah Dinasti Ching berkuasa di Cina (1644-1911) hubungan dagang dengan barat telah dibuka. Pelabuhan mereka yang pertama adalah Amoy, Kwantung dan Fukien. Meskipun hubungan dengan negara barat telah dimulai sejak tahun 1614 namun baru tahun 1786 penduduk setempat menyadari bahwa yang banyak mendapatkan keuntungan adalah negara Barat. Hal ini mendorong mereka mendengar bahwa di Semenanjung Malaya orang bisa mendapatkan mata pencaharian dengan upah yang banyak.

Orang Cina Perantau itu paling sedikit terdiri dari 4 suku bangsa yang berbeda satu dengan yang lainnya dan juga berbeda bahasa mereka, namun bagi orang Indonesia, orang Cina itu hanya dikenal 2 jenis yaitu Cina Totok dan Cina Peranakan. Penggolongan dua jenis etnis Cina tersebut disamping perbedaan karena kelahiran juga perbedaan dalam tahap penyesuaian diri dengan budaya Indonesia. Cina Peranakan adalah yang lahir di Indonesia karena hasil perkawinan campuran antara orang Cina dengan orang Indonesia sedangkan Cina Totok adalah Cina yang lahir di negeri asalnya Cina.

Penggolongan ini juga menyangkut soal derajat penyesuaian dan akulturasi dari para perantau Cina (Overseas Chinese) terhadap kebudayaan Indonesia yang ada disekitarnya, sedangkan derajat akulturasi itu tergantung kepada jumlah generasi para perantau itu telah berada di Indonesia dan kepada intensitas perkawinan campuran yang telah terjadi (Usman 1996).

Setelah berakhirnya tanam paksa di Hindia Belanda (1830-1870) maka dimulailah suatu era baru yang dikenal dengan masa liberalisme. Ciri utama masa ini adalah digantikannya fungsi pemerintah di bidang perekonomian oleh modal swasta. Pemerintah Hindia Belanda melaksanakan hal-hal yang khusus seperti sebagai pengumpul pajak, mengusahakan pegadaian, memonopoli garam dan perdagangan candu. Dalam situasi seperti ini maka Orang Cina tetap penting peranannya dalam perdagangan perantara.

Pada waktu perdagangan dapat dibagi menjadi tiga kelompok, yaitu perdagangan besar yang dikuasai oleh pemerintah Hindia Belanda. Perdagangan kecil yang diperankan oleh pribumi, sebagai bangsa jajahan, dan perdagangan perantara sebagai penghubung antara perdagangan besar dengan perdagangan kecil yang didominasi oleh perdagangan Cina. Sebagai pedagang sementara, Orang Cina menguasai perdagangan distribusi dan perdagangan koleksi. Perdagangan distribusi terutama menyebarkan barang-barang konsumen yang diimport dari luar negeri. Sebagai 
pedagang koleksi, Orang Cina menguasai pengumpulan hasil-hasil tanaman dagang dari petani yang diteruskan kepada pedagang besar (Usman dkk 1996).

Faktor-faktor yang menentukan keberhasilan pedagang Cina adalah

1. Faktor tumbuhnya mobilitas idealisme dalam bentuk untuk mencapai taraf kehidupan yang lebih baik dari apa yang mereka capai di negeri asalnya.

2. Orang Cina terinspirasi dengan ajaran konfusius yang lebih menekankan hubungan sesama manusia. Pandangan ini melahirkan etos kerja seperti keuletan dalam bekerja, tekun.

3. Orang Cina mempunyai modal yang besar dan mendapat dukungan dari Indonesia sendiri dan Hindia Belanda.

4. Pedagang Cina mengembang usaha di tempat yang tidak ada saingan seperti daerah-daerah pertanian.

5. Adanya peraturan dari Hindia Belanda bahwa Orang Cina mempunyai kedudukan yang lebih tinggi dari orang pribumi (Ibid).

\section{Penutup}

Golongan etnis Cina di Indonesia seringkali diidentifikasikan sebagai golongan yang mempunyai peranan penting dalam dunia perekonomian di Indonesia. Walaupun sebetulnya tidak semua orang Cina mempunyai bakat dalam dunia bisnis. Berdasarkan bukti-bukti arkeologi yang ditemukan di Indonesia mengisyaratkan bahwa etnis Cina pernah berjaya di Indonesia dan bahkan sampai sekarang. Golongan ini membentuk pemukiman di berbagai daerah di Indonesia dengan aktivitas berdagang, jadi pekerja tambang, serta mempunyai keturunan Indonesia Cina. Dominasi perekonomian oleh migran Cina bukan merupakan bencana buat bangsa Indonesia tetapi merupakan cermin buat Indonesia untuk melangkah ke depan. 


\section{KEPUSTAKAAN}

Hall, D.G., 1998. Sejarah Asia Tenggara. Surabaya: Usaha Nasional

Kusmartono, Vida Pervaya Rusianti dan Andi Nuralang., 2000. Kehidupan Sosial Ekonomi dan Perdagangan Di daerah Pesisir Tenggara Kalimantan. Berita Penelitian Arkeologi Nomor 08. Banjarmasin: Balai Arkeologi Banjarmasin.

Natsir, Muhammad. 1999/2000. Cina Makassar. Artikel Somba Opu Vol. 5 No.8 Oktober 1999 - Maret 2000. Ujung Pandang: Suaka Peninggalan Sejarah dan Purbakala Provinsi Sulawesi Selatan dan Tenggara.

Tjeng, Lie Tek., 1998. Cina Perantau di Asia Tenggara Konsiderasi dan Problem Etnisitas. Artikel Jawa Pos selasa, 29 September 1998, halaman 4.

--------, 1998. Cina Perantau di Asia Tenggara Terbelenggu Istilah Overseas Chinese. Artikel Jawa Pos Rabu, 30 September 1998, halaman 4.

Usman, H.A.Gazali, H.Ramli Nawawi, Fahrurazie., 1996. Integrasi Nasional Suatu Pendekatan Budaya Daerah Kalimantan Selatan. Banjarmasin: Prisma Muda Banjarmasin. 